\title{
Structural setting of the Apennine-Maghrebian thrust belt
}

1 Dep. of Earth Sciences, University of Pisa, Via S. Maria 53, I-56126 Pisa, Italy.

2 Dep. of Geological Sciences, University of Catania, Corso Italia 55, I-95129 Catania, Italy.

3 Dep. of Geological Sciences, University "Roma Tre", Largo S. Leonardo Murialdo 1, I-00146 Rome, Italy.

4 Dep. of Earth Sciences, University of Torino, Via Accademia delle Scienze 5, I-10123 Torino, Italy.

The Apennine-Maghrebian fold-and-thrust belt developed from the latest Cretaceous to Early Pleistocene at the subduction-collisional boundary between the European and the westward-subducted Ionian and Adria plates. Large parts of the Mesozoic oceanic lithosphere were subducted during an Alpine phase from the Late Cretaceous to Middle Eocene. The chain developed through the deformation of major paleogeographic internal domains (tectono-sedimentary sequences of the Ligurian-Piedmont Ocean) and external domains (sedimentary sequences derived from the deformation of the continental Adria-African passive margin). The continuity of the Apennine chain is abruptly interrupted in the Calabrian Arc by the extensive klippe of KabyloCalabrian crystalline exotic terranes, derived from deformation of the European passive margin.

Major complexities (sharp deflections in the arcuate configuration of the thrust belt, out-ofsequence propagation of the thrusts) are referred to contrasting rheology and differential buoyancy of the subducted lithosphere (transitional from continental to oceanic) and consequent differential rollback of the Adria plate margin, and to competence contrasts in the Mesozoic stratigraphic sequences, where multiple décollement horizons at different stratigraphic levels may have favored significant differential shortening.

From the Late Miocene, the geometry of the thrust belt was strongly modified by extensional faulting, volcanic activity, crustal thinning and formation of oceanic crust correlated with the development of the Tyrrhenian Basin.

\section{Introduction}

The large-scale geometry of the Apennine-Maghrebian chain is that of an arcuate thrust belt with convexity towards the Adria-Africa foreland. Nested arcs of different size and curvature show a progressive change from the WNW-ESE trends of the Torino and Monferrato hills, to the Ferrara fold-and-thrust belt beneath the Po Plain, the NNW-SSE trends of the Marche and Abruzzi segment, the NW-SE trends in Molise-Puglia-
Lucania, and the N-S trends in Calabria, which gradually deflect E$\mathrm{W}$ in Sicily (Figure 1). The Apennine-Maghrebian fold-and-thrust belt developed from the latest Cretaceous to the Early Pleistocene at the subduction-collisional boundary between the European and the westward-subducted Ionian and Adria plates. Large parts of the Mesozoic oceanic crust were subducted during an Alpine phase, from the Late Cretaceous to Middle Eocene; starting in the Oligocene, continental collision of the European margin occurred against the Adria-Apulia-African margin. From the Late Miocene, the geometry of the thrust belt was strongly modified by extensional faulting, volcanic activity, crustal thinning and formation of oceanic crust in the southern Tyrrhenian Sea.

The Apennines comprise a stack of Adria-verging thrust sheets bounded by a complex system of frontal arcs, which overlie with a festoon-like pattern the upper Pliocene-lower Pleistocene terrige-

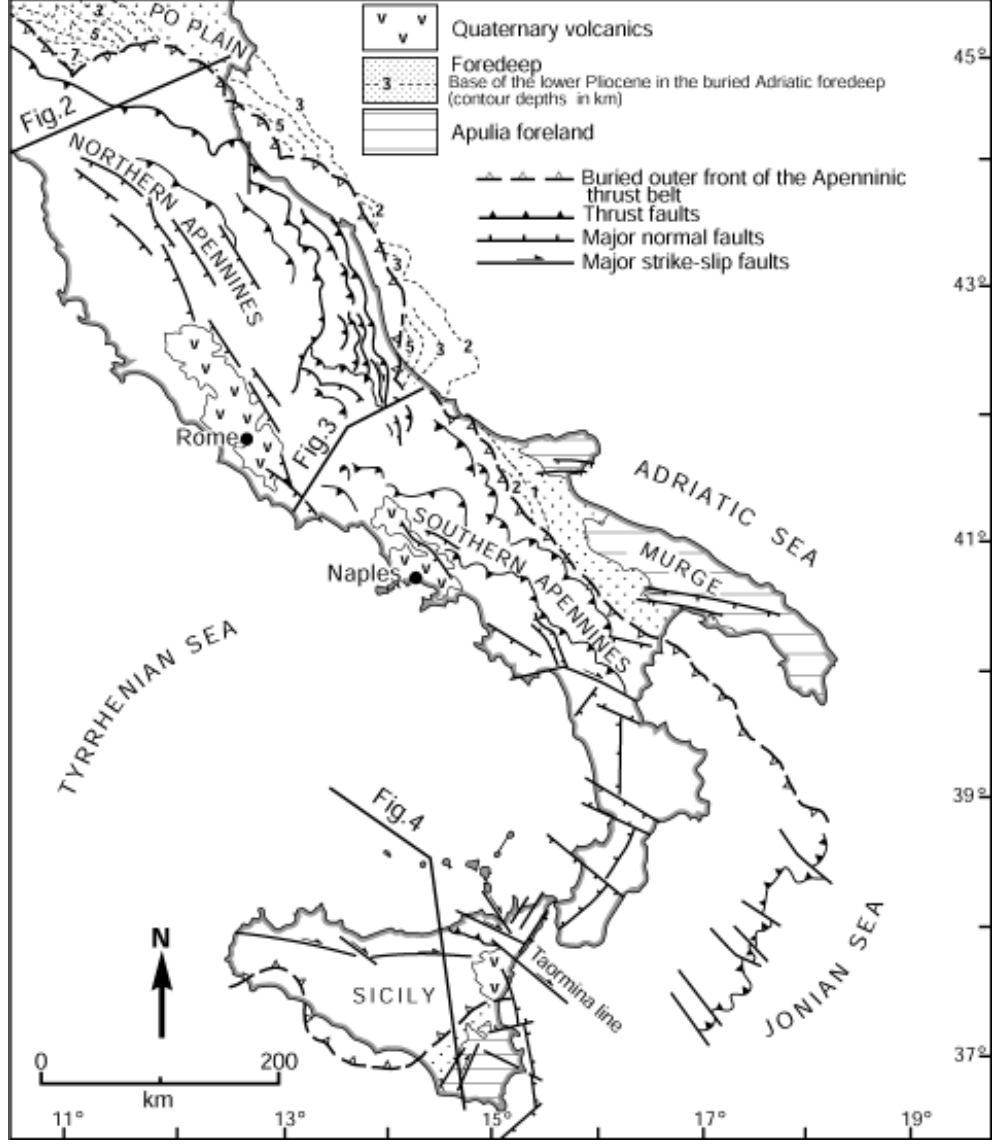

Figure 1 General structural map of the Apennine-Maghrebian chain. Fig.2, Fig.3, Fig.4: locations of the cross-sections of Figures 2-4. (After Ghisetti and Vezzani, 1999, modified) 
nous sequence of the Adriatic foredeep and the slightly deformed margin of the Adria foreland. The Maghrebian chain in Sicily shows a stack of thrust sheets verging toward south, where part of the Hyblean foreland crops out.

Within the Apennine chain, tectonic segmentation and changes in structural trends are controlled by partitioning of thrusting and strikeslip transfer along transverse discontinuities connected with thinskinned differential rotations. The degree of shortening varies irregularly according to the inherited paleogeography, contrasting rheology and differential sinking and roll-back of the subducting plate.

The chain developed through the deformation of two major paleogeographic domains: the internal domain, i.e. Late Jurassic to Oligocene tectono-sedimentary sequences of the Ligurian-Piedmont Ocean, which originally was linked to the Tethyan Sea, and the external domain, i.e. Triassic to Early Miocene sedimentary sequences derived from the deformation of the continental AdriaAfrica passive margin.

The continuity of the Apennine-Maghrebian chain is abruptly interrupted in the Kabylo-Calabrian Arc by huge volumes of crystalline basement rocks and related Mesozoic-Paleogene carbonate covers thrust over Cretaceous to Miocene basinal sequences, belonging to the Liguride Units in northern Calabria and to Sicilide Units in Sicily.

This paper attempts to synthesize the content of a large volume of published papers; due to the breadth of the discussed topic, quoted references are not comprehensive but were selected to guide readers through literature.

\section{The Kabylo-Calabride terranes}

The orogenic hinterland mostly consists of metamorphic Calabride basement units, largely submerged offshore northern Sicily but cropping out in northeast Sicily (Peloritani Mts.) and in Calabria, and linked westwards to the Kabylies of North Africa.

These exotic terranes, referred to as Calabride units, are located at the intersection between the NW-SE-trending southern Apennines and the E-W-trending Sicilian Maghrebides. They are characterized by a pre-Mesozoic crystalline basement, and show evidence of preAlpine tectonism and a wide range of metamorphic processes (Bonardi et al., 2001). In the Peloritani Mountains (Sicily) and Calabria, several tectonic units are believed to derive from a former "internal massif" consisting of crystalline terrains (with metamorphic grade increasing from outer to inner zones) transgressively covered by different Mesozoic to Tertiary sedimentary sequences characterized by thinning and later subsidence toward the interior. In Calabria, the crystalline nappes and their related non-metamorphic Mesozoic-Paleogene carbonate covers were thrust northward onto the Liguride ophiolitic unit. In Sicily, the front of the Calabride units, which were thrust onto the Cretaceous-Miocene basinal sequences of the Sicilide Complex, has been traced across the Nebrodi-Peloritani chain from the Tyrrhenian Sea to the Ionian Sea along the Taormina Line (Figure 1).

\section{Internal domain}

This domain includes the Liguride units and Sub-Liguride units that crop out extensively in the northern Apennines, western Alps, and in the southern Apennines and Sicily, where the latter are described as Sicilide units.

The Liguride and Sicilide units experienced "Alpine" tectonics before being thrust onto the domains of the Adria-Africa continental margin. This tectonic phase leads to the Late Cretaceous-Middle Eocene clo- sure of the Liguride-Piedmont oceanic basin, probably in relation to east-dipping subduction. The subsequent thrusting of the Liguride, Sub-Liguride and Sicilide units onto the outer domains was due to "Apennine" tectonics, which developed during Oligo-Miocene westdipping subduction, and to continent collision connected with the migration of the Sardinia-Corsica continental block and opening of the Balearic Basin.

\section{Liguride units}

The northern Apennine Liguride units are ascribed to two different paleogeographic areas, one Internal (IL) and the other External (EL). The IL units are characterized by a basement mainly consisting of serpentinized peridotites, regarded as exhumed lithosphere, intruded by gabbros in the Permian, i.e. before the opening of the ocean. This basement (peridotites + gabbros) was exhumed in the Late Jurassic up to the sea floor. The overlying volcano-sedimentary sequence includes basalts and ophiolitic breccias topped by Late Jurassic to Late Cretaceous radiolarites, Calpionella-bearing Limestones and Palombini Shales. The latter formation is overlain by CampanianEarly Paleocene siliciclastic turbidites (Val Lavagna Shales and Gottero Sandstones) representative of a deep-sea fan fed by the European continental margin. Early Paleocene ophiolite-bearing debris flow deposits, fed by an Alpine accretionary wedge, represent the last sedimentary deposits preserved in the IL units.

The EL units are characterized by thick successions, mainly Late Cretaceous carbonate turbidites (Helminthoid Flysch), in which the ophiolites only occur as slide blocks or as fragments in coarsegrained deposits. These turbidites are overlain, mainly in the easternmost areas, by carbonate turbidites of Paleocene-Early Eocene age. Helminthoid Flysch is characterized by basal complexes consisting of coarse-grained clastic deposits of Albian-Campanian age; these deposits are ophiolite bearing in the westernmost areas, whereas they are fed by a continental margin in the easternmost ones. Although all EL unit successions are detached from their basement, the basal complex in the westernmost areas shows evidence of a basement: an ocean-continent transition characterized by the association of subcontinental mantle, granulites and continental granitoids s.l. By contrast, the analysis of basal complexes in the easternmost areas reveals that they were fed by the Adria continental margin.

The IL and EL units are characterized by a different structural history (Figure 2). The IL units display a west-verging evolution in the Alpine accretionary wedge. This evolution predates the eastward thrusting over the EL units, which are characterized by mainly eastvergent deformation. The Middle Eocene-Miocene deposits of the Epi-Ligurian Basin, a thrust-top basin above the Liguride units, seal the contacts among IL and EL units.

In the southern Apennines the Liguride units (also referred to as "Liguride complex") consist of a Mesozoic-Paleogene deep-water sequence interpreted as a detached sedimentary cover of the Liguride-Piedmont oceanic crust. The sequence has been subdivided into the Frido and Cilento tectonic units. The lowermost Frido Unit underwent a HP/LT subduction-related event followed by a greenschist-facies re-equilibration; this unit, cropping out in southern Lucania and northern Calabria, was thrust above the limestones of the Apennine platform and lies beneath the Cilento Unit. The Frido metasedimentary sequence consists of a highly variable alternation of shales, quartzarenites, and silty and arenaceous limestones of Neocomian-Albian age; it includes slices of Late Jurassic-Early Cre-

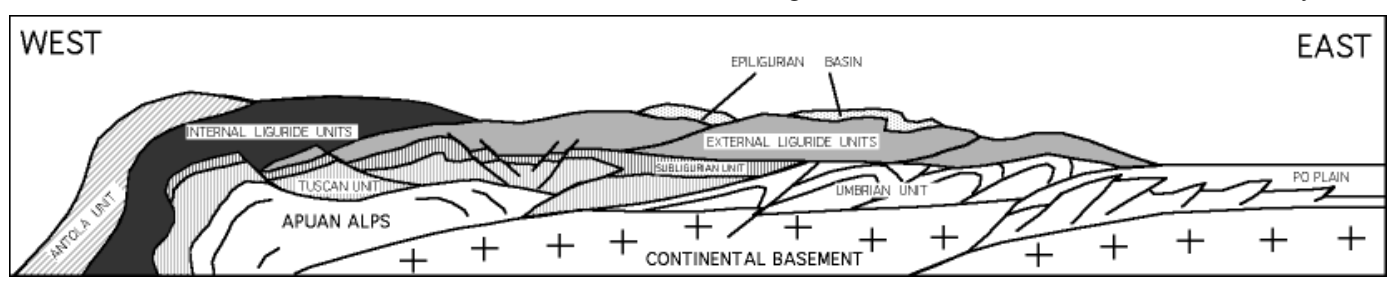

Figure 2 Schematic cross-section showing the geometric relations among the major structural units of the northern Apennine. For location, see Figure 1. (P. Elter) 
taceous pillow lavas, diabase breccias, radiolarian cherts, jaspers and cherty limestones.

The uppermost Cilento (or Flysch Calabro-Lucano) sequence crops out from the Tyrrhenian coast to the Ionian slopes of Mt. Pollino. It includes a basal Crete Nere Fm, which consists of prevailing black shales alternating with siliceous calcilutites, marls and graded quartzarenites of Aptian-Albian age. The Pollica-Saraceno Fm lies above, i.e. turbiditic calcarenites and lithic-arkosic sandstones alternating with calcilutites and local conglomerates of Cenomanian to Paleocene age. The Cilento sequence is unconformably covered by the Albidona-S. Mauro Fm, which consists of 2,000 m of alternating siltyargillaceous marls in beds of up to $10 \mathrm{~m}$, well-bedded sandstones with megabeds of calcilutites, and conglomerates with crystalline, calcareous clasts and predominant matrix; the age of this formation is still debated (Early-Middle Eocene, Vezzani, 1966; Baruffini et al., 2000; Miocene, Bonardi et al., 1985).

\section{Sub-Liguride units and Sicilide units}

Sub-Liguride units occur between the Liguride and TuscanUmbrian units (external domain, described later). The Sub-Liguride units display successions characterized by Late Cretaceous-Early Eocene shales and carbonates, showing Ligurian affinity, and arenites and conglomerates of Late Eocene-Early Oligocene age; the latter are characterized by andesitic clasts probably connected with Alpine subduction.

In the central-southern Apennines and Sicilian thrust belt, the Sicilide units (also known as "Sicilide Complex") consist of a nonophiolite-bearing, varicolored pelitic sequence of intensely deformed, Late Cretaceous-Early Miocene deep-marine sediments. The sequence includes a red and green basal pelitic member with intercalations of cherty limestones and quartzarenites (Mt. Soro Fm), which gives way above to alternating calcarenites, calcirudites and marly limestones (Pomiere facies, in Sicily, and Mt. Sant'Arcangelo facies, in Lucania), and to alternating andesitic tuffites and tuffitic sandstones, marly shales and marly limestones of Oligocene-Early Miocene age (Tusa facies, in Sicily and Lucania).

A large part of this varicolored sequence (the so-called "Argille scagliose") prevailingly crops out at the boundary between the Apennine thrust front and the Po Valley-Adriatic-Ionian and Catania-Gela foreland basins. Note that the attribution of this varicolored sequence to the Lagonegro succession (see External domain) rather than to the Sicilide units is in many cases matter of debate. This strongly deformed pelitic sequence constitutes the matrix of a fragmented formation, which derived from polyphase deformation of original pelitic, calcareous and arenitic multi-layered sequences along the Apennine accretionary frontal prism. This tectonic mélange includes slices of different size of resedimented calcarenites and calcilutites, cherty limestones, and quartzites pertaining to the Late Cretaceous section of the internal units, as well as fragments of Early Miocene Numidian quartzarenites and Tusa tuffites.

\section{External domain}

The large-scale structure of the entire Apennine Maghrebian chain is characterized by the thrusting of the Liguride, Sub-Liguride and Sicilide units onto the outermost domains, i.e. Tuscan and Umbria-Marches units in the northern Apennines, Latium-Abruzzo-Molise units in the central Apennines (Figure 3), Daunia-Lucania units in the southern Apennines and Mt. Iudica-Sicani Mts. in Sicily; as a whole, these units occupy the lowermost position in the thrust belt.
The Meso-Cenozoic stratigraphic successions outcropping in the external domain mainly accumulated along the Adria-Africa passive continental margin. The successions developed through a combination of geological processes. Of these, the most important were crustal extension, the cyclic production of marine carbonates and sea-level variations. The most ancient deposits, representing a long Late Triassic depositional phase in evaporitic to restricted-marine (dolomites with anhydrite levels) environments, directly onlap Permian continental deposits. A vast carbonate platform of regional extent began to develop at the start of the Jurassic. Subsequently, still in the Early Jurassic, the entire area experienced a rifting phase, which gave rise to a complex marine topography with various (especially carbonate) depositional environments.

\section{Carbonate platform successions}

The continental shelf deposits were characterized by the development of isolated peritidal carbonate platforms, pelagic basins and, locally, of pelagic carbonate platforms (portions of flooded peritidal platforms covered by condensed, discontinuous pelagic carbonate successions, such as the Sabine Plateau, in Latium). The strong topographic control of sedimentation ceased in the Early Cretaceous and was substituted by general natural processes (sea-level variations, currents, changing subsidence velocities, synsedimentary tectonics, etc.), which produced large lateral variations in carbonate sedimentation.

Remnants of a vast Apennine carbonate platform (or perhaps of several platforms separated by seaways) have been divided into several tectonic units that constitute the bulk of the central-southern Apennine thrust belt. The remnants of the Apulian carbonate platform, which acted as a foreland and was only partially involved in orogenic deformation, crop out east of the Apennine chain. Minor remnants of carbonate platform also outcrop in the Palermo and Madonie Mts. (northwestern Sicily). This succession consists of Late Triassic-Jurassic-Cretaceous reefal carbonates overlain by Late Cretaceous-Eocene wackestones and red marls exhibiting a typical Scaglia facies, Oligocene fine-grained marls, quartzarenites and calcarenites. Along the southern border of the Madonie Mts., this carbonate platform is characterized by swarms of platform carbonate blocks and megabreccias embedded within the brown shales of the Numidian Flysch. A platform carbonate sequence resting on volcanic seamounts also crops out in the Hyblean Plateau (southeastern Sicily), where it acted as the foreland of the Maghrebian thrust belt.

Environmental changes have continuously influenced the evolution of platforms in the Apennine-Maghrebian chain: in the Cenomanian, the breakup and flooding of the former Bahamian-type platforms gave rise to highly productive margins controlled by faults. As a result, the inner platform areas diminished, with the development of vast carbonate ramp systems which linked amply emerged portions of ancient platforms to the surrounding pelagic basins (Parotto

$$
\text { ISW }
$$

NE | WSW

ENE|

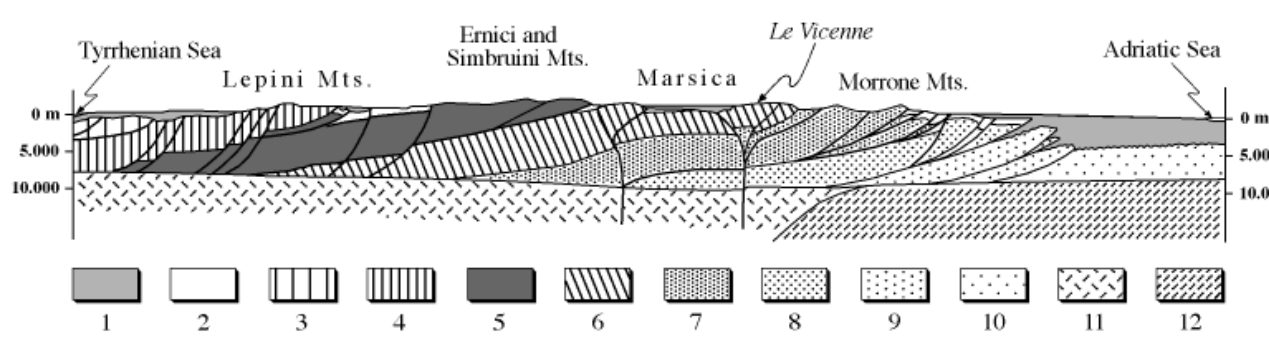

Figure 3 Schematic cross-section of the central Apennine thrust belt. For location, see Figure 1. 1. marine and continental post-orogenic sedimentary cover (Tyrrhenian side) and intermountain basins (Late Messinian-Quaternary); marine syn-and post-orogenic deposits (Adriatic side: early Pliocene-Quaternary); 2. syn-orogenic deposits (late Tortonian to early Pliocene); 3-9. tectonic units mainly derived from the external domain (carbonate platforms and basins); 10. Adriatic foreland; 11. magnetic basement of the thrust belt; 12. magnetic basement of the Adriatic foreland. (From Cipollari et al., 1999) 
and Praturlon, 1975). Starting in the Middle Miocene, shallow water calcarenites unconformably or paraconformably overlay the Cretaceous limestones (the so-called "Paleogene hiatus", well known in the central-southern Apennines) of the ancient, Mesozoic carbonate platforms; siliciclastic turbidites deposited in later Miocene-early Pliocene above the middle Miocene calcarenites.

\section{Pelagic Basin successions}

Pelagic basins developed around and between the platforms. The Sabine Basin opened to the west of the Apennine platform and was linked to the Tuscan Basin (the Sabine Plateau lay within these basins). The Umbria-Marche Basin lay to the north and was also linked to the Sabine and Tuscan basins. The Lagonegro-Molise Basin opened between the southern Apennine and Apulian platforms, while an outer basin (Ionian Basin) opened east of the Apulian platform. In Sicily an inner basin (Imerese Basin), which may be correlated with the Lagonegro Basin, widely crops out in the northern part of the island, while an outer basin (Sicani Basin) opened in the southwestern part of the island.

In the northern Apennines, the basin successions from Tuscany and Umbria-Marche started with a transgressive event (Triassic Verrucano-facies conglomerates, evaporites and dolostones covered by platform carbonates of Liassic age), followed by progressive sinking marked by the Rosso Ammonitico-facies deposits, older in the Tuscan zone (Sinemurian) than in the Umbria zone (Aalenian). The deepest pelagic deposits are represented by Upper Jurassic-Lower Cretaceous radiolarites and pelagic limestones (Maiolica facies), and are coeval with the older sedimentary deposits found in the LiguridePiedmont oceanic basin.

The Umbria-Marche succession merges southward into the Sabina succession, in which limestones, marly limestones, marls and cherty levels alternate with frequent intercalation of resedimented rocks derived from the carbonate platform margin.

The paleogeographic features of the platform-basin system in the northern-central Apennines remained the same through to the Oligocene, when the structuring of the Apennine orogen had already begun. The inception of flexuring of the Adria continental margin in the Middle-Late Oligocene led to the development of the foredeep basin system, which was filled by thick siliciclastic turbiditic bodies. Infilling progressively shifted from internal to external zones (from the Oligocene for the Tuscan zone to the Early Pliocene for the outermost peri-Adriatic zones) due to the progressive migration of the orogenic belt-foredeep couple.

The evolution of the Lagonegro-Molise Basin (southern Apennines) and of the Imerese-Sicani Basin (central-north Sicily) was rather different. The basinal sequences of the Lagonegro and Imerese basins show a transition from terrigenous-carbonatic facies of coastal to shallow-water environments (Early Triassic-Anisian), to pelagic cherty-radiolaritic facies (Ladinian) followed by cherty limestones of Late Triassic age, dolomites and by a Jurassic-Cretaceous radiolarites succession with mafic volcanics and more or less pronounced hiatuses. The overlying Middle-Late Eocene to Early Oligocene sequence is composed of interbedded red marls and graded calcarenites with macroforaminifera. On it rests the alternation of quartzarenites and clays of the Numidian Flysch, which represents the earliest Late Oligocene to Middle Miocene filling of the precursor foredeep basins established after the collision between the African and European continental plates. In the outermost zones of the Apennine chain (e.g. the Molise Basin, Daunia, and Lucania "external zones") and in Sicily, the Numidian Flysch is overlain by alternating marly limestones, calcarenites and calcirudites with reworked upper Miocene macroforams (e.g. Tufillo Fm, Masseria Palazzo Fm) grading to Tortonian (in part)-Messinian marls (Orbulina Marl Fm). These are followed by the siliciclastic turbidites of the Agnone Flysch in Molise and the Masseria Luci Flysch in Lucania, representing the Messinian stage of the eastward migration of the foredeep basin, which shifted up to the Bradanic-Gela-Catania foredeep in the Early Pliocene.

The reconstructed setting suggests that Numidian Flysch deposited over a large basin, the external side of which was represented by a still undeformed African plate margin. The internal margin of the Numidian Flysch basin is more difficult to reconstruct because of subsequent intense deformation and crustal shortening during the formation of the Apennine-Maghrebian chain. Although most of the original stratigraphic contacts between the Numidian Flysch and its substratum are overprinted by later tectonic detachments, it is still possible to infer the stratigraphic substratum of the Numidian Flysch, represented by both platform and pelagic basin carbonates and by deformed successions of the Sicilide domain.

\section{Epi-Liguride sequence (piggyback basins, Ori \& Friend, 1984; satellite basins, Ricci Lucchi, 1986; thrust-top basins, Butler \& Grasso, 1993)}

This is the well-known Oligocene-Pliocene lithostratigraphic sequence comprising Monte Piano Marls, Ranzano Fm, Antognola Fm, Bismantova Group, Termina Fm and Gessoso-solfifera Fm. The sequence is characterized by relatively deep-marine deposits, with episodes of shallow marine and transitional-continental (lagoon and fan delta) deposition, which unconformably cover the already deformed Liguride and Sub-Liguride allochthon of the PiedmontLiguride and Emilian thrust belt.

In the central Apennines, correlated thrust-top sequences (Rigopiano, Monte Coppe, Calaturo) of early Pliocene age unconformably cover the carbonatic sequences of the Gran Sasso and Mt. Morrone thrust belt.

In the southern Apennines, many Middle-Late Miocene clastic deposits (e.g., Gorgoglione Fm and Oriolo Fm in Lucania, Anzano Fm in Puglia, Valli Fm in Molise), followed by the Messinian Gessoso-solfifera Fm and lower Pliocene clayey conglomerate sequence (Panni in Puglia, Larino in Molise), unconformably cover both the Sicilide allochthon and its substratum, mainly represented by the Lagonegro-Molise units. Thrust-top basins are also present in the Calabrian Arc (Crotone and Spartivento basins) and Sicily (in the northern part of the Caltanissetta Basin), where the Late Miocene Terravecchia Fm represents a clastic sediment deposited above and adjacent to growing thrusts and folds. Towards the chain, the Terravecchia Fm lies directly above thrust structures, thus representing the infill of one or more basins perched on thrust sheets. Two major Messinian evaporitic successions, separated by regional erosional and/or angular unconformities, and the Early Pliocene Trubi chalks were involved in the thrust-fold belt of central Sicily (Decima \& Wezel, 1971; Butler et al., 1995a).

In the northern Apennines and Sicily, these sequences are characterized by several chaotic resedimented breccia bodies related to submarine mass gravity transport of material derived from the Liguride and/or Sicilide substratum ("Argille Brecciate").

\section{Large-scale tectonic features of the Apennine-Maghrebian thrust belt}

The Apennine-Maghrebian chain as a whole is characterized by the superposition of two major geometric units that configurate a regional, east-verging duplex structure separated by a low-angle, west-dipping regional thrust system. This allochthonous edifice tectonically overrides the Adria-Hyblean foreland, as well documented at and below the surface by seismic and drilling exploration (Mostardini \& Merlini, 1986).

The uppermost tectonic element consists of allochthonous Liguride, Sub-Liguride and Sicilide nappes, which involve MesozoicCenozoic sedimentary sequences and ophiolitic suites derived from 
deformation of the internal domains. Prior to thrusting, these units were more or less involved in Alpine tectonics. The upper part of the Liguride complex in the westernmost areas and Elba Island followed a meso-Alpine, European-verging evolution before being thrust above the domains of the Adria continental margin. In turn, the lower complex, mainly represented by External Liguride units, was affected by a Middle Eocene tectonic event. As a whole, the Liguride-Sicilide stack shows a foreland-dipping geometry and a thinskinned imbricate structure.

The underlying tectonic element is represented by the outer foreland fold-and-thrust belt, consisting of tectonic units derived from the deformation of the Adria margin, i.e., the Tuscan-UmbriaMarche units of the northern Apennines, the Latium-Abruzzo and Lagonegro-Molise units of the central-southern Apennines, and the Panormide-Imerese-Sicanian units of Sicily. The large-scale tectonic structure of the northern Apennines can be clearly observed in the Apuane Alps window, where a complete section of these tectonic units crops out. The lowermost tectonic unit is the low-grade metamorphosed Tuscan unit, represented by a Triassic to Oligocene sedimentary cover involved, along with slices of Paleozoic basement, in large-scale structures. This unit was overridden by the unmetamorphosed Tuscan unit, only represented by the Triassic to Miocene sedimentary cover, which detached along the Triassic evaporites. In the central-southern Apennines and in Sicily, the Tertiary sequences of these external units were decoupled from their Mesozoic substratum and pushed, together with the overlying Sicilide and Liguride units, to form the outermost imbricate thrusts that lie directly above the Bradano-Gela-Catania foredeep and the Apulia-Hyblean foreland.

A further major geometric unit at the top of the ApennineMaghrebian chain is represented by the extensive klippe of KabyloCalabride crystalline exotic terranes derived from deformation of the European passive margin, which overrode both the Liguride-Sicilide nappes and the outer foreland fold-and-thrust belt. These units are submerged in the Tyrrhenian Sea. In the Peloritani Mts. and Calabria (Calabrian Arc), the crystalline nappes and their related MesozoicPaleogene carbonate covers are thrust over Cretaceous to Miocene basinal sequences deposited in oceanic and/or thinned continental crust, which was consumed during the early phases of the collision. Most of the arc lies offshore, and its structure and geometry have been mainly reconstructed through the analysis of available multichannel seismic profiles (Finetti, 1982; Finetti and Del Ben, 1986). A series of thrusts, progressively more pronounced in the central sector of the arc, affect the sedimentary sequences of the Ionian Basin. Seismic data highlights a prominent shear surface that progressively deepens toward the inner part of the arc.

All these three major geometric units are dissected by strikeslip and normal faults that post-date thrust structures and in some cases control the opening of minor marine and/or continental basins.

\section{Kinematic reconstruction}

The large-scale tectonic evolution of the Apennine thrust belt was firmly constrained by the progressive eastward migration of the outer Apennine front, related to the opening of the Tyrrhenian Basin. The progressive shortening of fold-and-thrust belt is traced by the onset, evolution, deformation and progressive migration of Late Miocene to Early-Middle Pliocene siliciclastic foredeep deposits.

The three main steps in the contractional evolution of the Tyrrhenian-Apennine system have been reconstructed by Patacca et al. (1990).

Late Tortonian-Messinian (in part) rifting in the northern Tyrrhenian Sea, southwestern Tyrrhenian Sea and Gioia Basin was contemporaneous with the eastward shifting of the foredeep-foreland system. This migration can be followed from the TuscanyUmbria (Macigno, Marnoso-Arenacea) to the Marches (Laga) foredeep basins in the northern Apennines, from the Latium (Frosinone, Torrice Flysch) to the Abruzzo (Laga, Gran Sasso Flysch) foredeep basins in the central Apennines, and from the Campania (AlburnoCervati) to the Molise-Lucania (S. Elena, Agnone and Masseria Luci Flysch) foredeep basins in the southern Apennines. This foreland fold-and-thrust belt, which represents the lower panel of the Apennine duplex, is overridden by the Liguride, Sub-Liguride and Sicilide nappes, which are unconformably overlain by the thrust-top deposits of the Valli, Oriolo and Gorgoglione Fms of TortonianMessinian age.

During the late Messinian-Pliocene (in part), extensional faulting affected the northern Tyrrhenian Basin and the western margin of the Apennine chain, as documented by syntectonic accumulation of Messinian "Lago-Mare" clastic deposits with evaporites, followed by lower Pliocene marine clays in southern Tuscany basins. In this interval, rift processes took place in the central bathyal plain of the southern Tyrrhenian Sea in connection with the opening of the Magnaghi-Vavilov and Issel basins. Extension was accompanied by eastward migration of the Apennine thrust, incorporation into the thrust belt of the former foredeep basinal areas, and eastward shifting of the upper Messinian-Pliocene foredeep siliciclastic deposits. Thrust-top basins filled with clastic deposits of late Messinian-Early Pliocene age developed in the southern Apennines (e.g. Potenza, Ofanto, Ariano Irpino) and Calabria (Crotone, Spartivento basins). During this interval, out-of-sequence thrusting connected with anticlockwise rotations was responsible for several major arcuate structures of the Apennine thrust belt (e.g., the Gran Sasso-Mt. Picca thrust, see Ghisetti \& Vezzani, 1991; Olevano-Antrodoco-Sibillini Mts. thrust, see Cipollari \& Cosentino, 1992).

During the Pliocene (in part) -Quaternary, extensional faulting migrated from the Tyrrhenian Sea to the internal margin of the Apennines, giving rise to the Lunigiana, Valdarno-Valdichiana, Mugello-Casentino, Valtiberina and Rieti basins. In the southern Tyrrhenian Sea, new rifting was responsible for the opening of the Marsili Basin southeast of the central bathyal plain. Along the Tyrrhenian margin of the southern Apennine chain, the eastward migration of extension and downfaulting produced the Volturno, Sele, Crati and Mesima basins, and was accompanied by a parallel migration of the thrust belt-foreland basin system. Several thrusttop basins preserved in structural depressions on the rear of the thrust front follow the arcuate setting of the northern and central Apennine belt from Piedmont to the Marches-Abruzzo. In the southern Apennines, large remnants of thrust top basins are preserved in Molise from Atessa to Larino and in Puglia-Lucania (Panni, S. Arcangelo).

In Sicily, the frontal thrust structures of the Maghrebian chain, involving strongly deformed Miocene to Pliocene sediments, are emplaced above Pliocene-Pleistocene rocks of the foreland margin (Butler et al., 1992). Along the margin of the bulged Hyblean foreland, normal faults accommodate flexural downbending (Figure 4). The Gela-Catania foredeep flanks the northern and western margins of the Hyblean Plateau, and extends offshore south-central Sicily. Within the Gela Nappe, the toe of a regional tectonic wedge coinciding with the Maghrebian thrust belt, compressional tectonics are reflected in folding and in thin-skinned thrusting, which post-dates the deposition of Pliocene sediments. North of the Gela Nappe, the Mt. Iudica imbricate thrusts consist of Mesozoic basinal carbonates and Miocene siliciclastics. Below the Mt. Iudica stack, the top of the impinging Hyblean bulge is no longer recognizable, but there is a dramatic change in the magnetic susceptibility of the basement in relation to a change in the carbonate substratum, i.e. the presence of a deep-seated duplex. Several thrust sheets consisting of Sicilide units and early foredeep deposits (Numidian Flysch), together with slices of their Mesozoic carbonate substratum, are detached from the basement. Small upper Miocene to Pliocene thrust-top basins lie above the thrust sheets. Other deformed Sicilide units are accreted at the junction between the Maghrebian chain and the CalabridePeloritani units, representing the orogenic hinterland. The Aeolian volcanic arc developed along the southern margin of the Tyrrhenian Basin. 


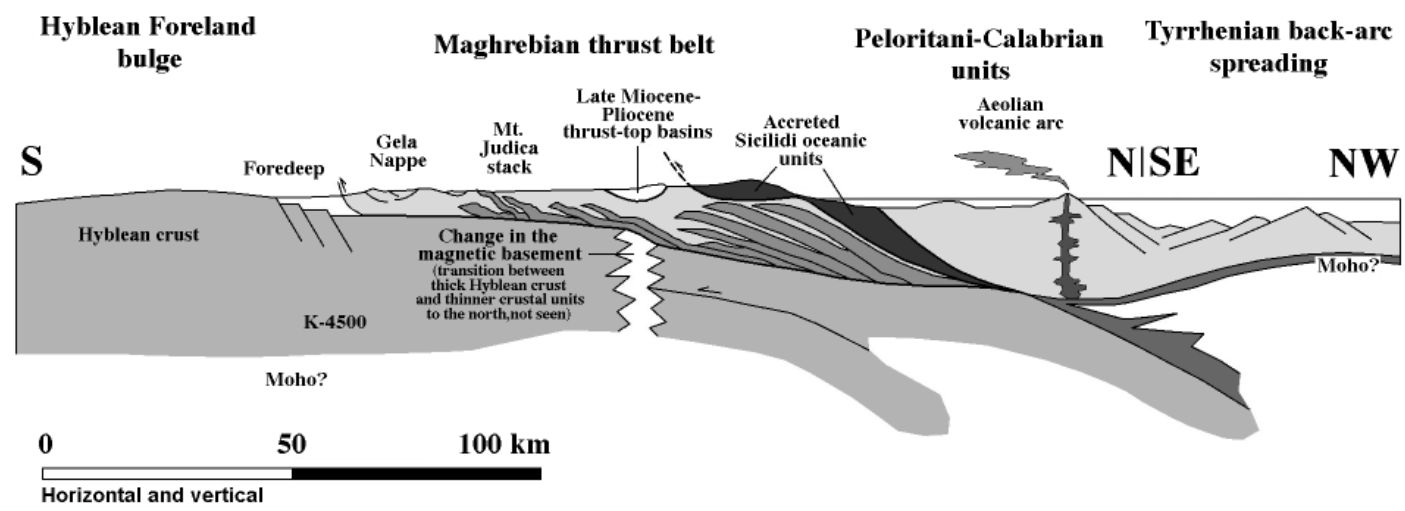

Figure 4 Simplified section across the eastern Sicily, from the Hyblean foreland to the southern Tyrrhenian back-arc basin; K indicates the magnetic susceptibility. For location, see Figure 1. (M. Grasso)

\section{Open issues and discussion}

The above traced evolution, which many authors have placed in the simple context of regular forward-migrating piggy-back imbrication of sedimentary units detached from a substantially undeformed crystalline basement (Bally et al., 1986), is in contrast with the observation that the leading thrust faults of the major tectonic units display different orientations, contrasting directions of tectonic transport, rotational emplacement trajectories, and out-of-sequence activation. The joint analysis of deformation styles, displacement gradients and age of shortening reveals that adjacent segments of the ApennineMaghrebian belt, with contrasting competence, underwent coeval deformation through non-coaxial kinematics.

All these observations constrain palinspastic reconstruction, section balancing and evaluation of the degree of shortening, and suggest extreme caution in deriving deformational steps and the regional trajectory of stress fields from the kinematics of fault systems.

The amount of extension in the Tyrrhenian Sea, shortening of the Apennine thrust belt, rates of foredeep migration and flexure retreat in the foreland, greater in the southern Apennines than in the northern Apennines, suggest that a single process was responsible for the genesis of the couple Tyrrhenian Sea-Apennine chain.

The Sicilian segment of the chain has a large dextral wrench shear component associated with the opening of the Tyrrhenian Sea during the Neogene, and is affected by relative motion between the African and European plates. The uplifted carbonates exposed in the western segment of the chain suggest that passive-margin sedimentation continued through much of the Paleogene. However, from the Late Oligocene onwards, deposition was predominantly siliciclastic, thus representing a dramatic change to foreland basin sedimentation. The highly rifted nature of the Mesozoic African continental margin during Tethyan spreading and its compartmentalization into a number of sub-basins brought about deposition in foredeep settings which remained deep-marine through much of the early Middle Miocene.

As previously mentioned, at the end of the Oligocene, and especially in the Miocene, the successions of the inner domains and of the platform-basin system of the central Apennine were involved in the progressive development of a thrust belt verging towards Adria. During this process, strongly subsiding sedimentary basins (foredeep) repeatedly developed along the thrust front of the orogen due to the progressive flexure of the foreland margin. The basins were filled with essentially siliciclastic turbidite successions (fed by sectors of the Alpine chain experiencing strong uplift, including magmatites and metamorphites, and by local contributions from the developing Apennine orogen). The diachronism of the turbidite successions highlights the progressive eastward migration of the foredeeps, especially in the Neogene, up to the present Adriatic foredeep. The thrust fronts migrated in the same direction, gradually involving the deposits of the various foredeeps and incorporating them in the chain (Cipollari et al., 1995).
Starting about $7 \mathrm{Ma}$ ago, while the Adriatic side of the chain was building up through compressional structures, intense extensional tectonics began to develop on the Tyrrhenian side. This extensional tectonic regime, which was directly correlated with the development of the Tyrrhenian Basin (further W), began to the west and migrated progressively eastward, involving a good portion of the chain. Its development led to the subsidence of entire sectors of the chain, which had only recently experienced uplift, through generally westward-dipping, high-angle normal fault systems (often reactivating, at great depths, the ramps of earlier thrust surfaces). The tectonic troughs, which consequently developed, accumulated thick marine (shallow water) to continental (fluvial, lacustrine) depositional sequences. Crustal thinning allowed the ascent of magma (both mantle-derived melts and magmas with varying degree of crustal contamination), which fed a chain of impressive volcanic edifices (with melts prevalently high in $\mathrm{K}$ ) at the site of the western, older and more mature extensional basins.

The presence of an extensional regime in the internal sector of the central-Apennine orogen that compensates compression towards the foreland has often been attributed to continuing lithospheric subduction in the presence of diminished convergence between Europe and Adria. Models propose an upwelling of the asthenosphere and a contemporaneous passive descent of a slab of subducting Adriatic lithosphere, with progressive eastward migration of the subduction hinge. However, some studies suggest that the slab broke away and is sinking. Other researchers believe that there is no conclusive evidence of subduction. They propose, instead, the presence of an asthenolith produced by transformations of the lithospheric mantle and crust induced by thermal anomalies and fluids from deep mantle sources. Whatever the cause, current processes in the ApennineMaghrebian chain seem to be in relation to general uplift and to the north-western migration of Africa and Adria with respect to stable Europe (Di Bucci \& Mazzoli, 2002).

\section{Acknowledgement}

Contributions by Michele Marroni, Boris Behncke and Giovanni Sturiale and the critical review of this paper by Antonio Praturlon and Daniela Di Bucci are gratefully acknowledged.

\section{References}

Bally, A.W., Burbi, L., Cooper C., and Ghelardoni, R., 1988, Balanced sections and seismic profiles across the central Apennine: Mem. Soc. Geol. It., v. 35, pp. 257-310.

Baruffini, L., Lottaroli, F., Torricelli, S., and Lazzari. D., 2000, Stratigraphic revision of the Eocene Albidona Formation in the type locality (Calabria, Southern Italy): Riv., Ital., Pal., Strat., v. 106, pp. 73-98. 
Bonardi, G., Ciampo, G., and Perrone, V., 1985, La Formazione di Albidona nell'Appennino calabro-lucano: ulteriori dati stratigrafici e relazioni con le unità esterne appenniniche: Boll. Soc. Geol. It., v. 104, pp. 539-549.

Bonardi, G., Cavazza, W., Perrone, V., and Rossi, S., 2001, Calabria-Peloritani Terrane and Northern Ionian Sea, in Vai, G.B., and Martini, I.P., eds, Anatomy of an Orogen: the Apennines and adjacent Mediterranean Basins, Kluwer Academic Publishers, pp. 255-286.

Butler, W.H.R., and Grasso, M., 1993, Tectonic controls on base-level variation and depositional sequences within thrust-top and foredeep basins: examples from the Neogene thrust belt of central Sicily: Basin Research, v. 5, pp. 137-151.

Butler, W.H.R., Grasso, M., and La Manna, F., 1992, Origin and deformation of the Neogene-Recent Maghrebian foredeep at Gela Nappe, SE Sicily: Journ. Geol. Soc. of London, v. 149, pp. 547-556.

Butler, W.H.R., Lickorish, W.H., Grasso, M., Pedley, M., and Ramberti, L., 1995, Tectonics and sequence stratigraphy in Messinian basins, Sicily: constraints on the initiation and termination of the Mediterranean salinity crisis: Geological Society of America Bulletin, v. 107, pp. 425-439.

Cipollari, P., and Cosentino, D., 1992: La linea Olevano-Antrodoco: contributo della biostratigrafia alla sua caratterizzazione cinematica: Studi Geologici Camerti, spec. v. 1991/2, pp. 143-149.

Cipollari, P., Cosentino, D., and Parotto, M., 1995, Modello cinematicostrutturale dell'Italia centrale: Studi Geologici Camerti, spec. v. 1995/2, pp. 135-143.

Cipollari, P., Cosentino, D., Esu, D., Girotti, O., Gliozzi, E., and Praturlon, A., 1999, Thrust-top lacustrine-lagoonal basin development in accretionary wedges: late Messinian (Lago-Mare) episode in the central Apennines (Italy): Paleogeo., Paleoclim., Paleoecol., v. 151, pp. 149-166.

Decima, A., and Wezel, F., 1971, Osservazione sulle evaporiti messiniane della Sicilia centro-meridionale: Rivista Mineraria Siciliana, v. 130-132, pp. $172-187$

Piero Elter, born in 1927, retired Professor of Geology at the University of Pisa. He received the Degree in Geology at University of Geneva in 1954. Piero Elter was Director of the Centro di Geologia Strutturale e Dinamica dell'Appennino of the CNR (Italian National Council of Research) from 1972 to 1988. His main research interests have been focused on the tectonic evolution of the Alps and the Northern Apennine. In particular, he has investigated the ophiolites from Northern Apennine and the implications for the origin of the oceanic lithosphere in the western Tethys.

Mario Grasso is Professor of Structural Geology at Catania University. Research expertise: stratigraphy, synsedimentary tectonics and geomorphological evolution of the Sicily-Calabrian region, regional field mapping, crustal structure of the Mediterranean region. He is leader of several National scientific projects concerning geological mapping and environmental risk assessment and member of the National Geological Committee.

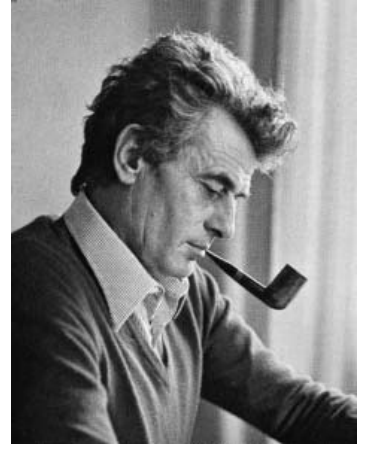

Maurizio Parotto is teaching Introduction to Geodynamics and Historical Geology at University "Roma Tre" (Italy). His research concentrates on stratigraphy and structural setting of central Apennine; at present he is Director of sub-project CROP 11 (CROsta Profonda, Deep Crust), a part of a CNR (Italian National Council of Research) project which involves the integration of crustal NVR seismic profiles with surface and subsurface geology in central Italy, from Tyrrhenian Sea to Adriatic Sea.

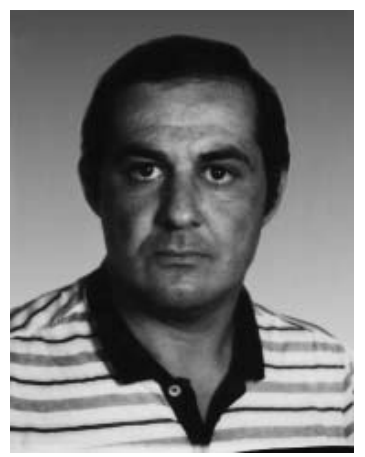

Livio Vezzani is Professor of Geology at Torino University. Expertise: Stratigraphic and structural analyses of fold-and-thrust belts, field mapping, editing and compilation of geological and regional tectonic maps, regional geology of the Mediterranean region, tectonic geomorphology, Quaternary geology, neotectonics, seismotectonics and seismic hazard assessment. Research activity has been ficused on the geodynamic evolution of the central and southern Apennine chain, Calabrian Arc and Sicily.
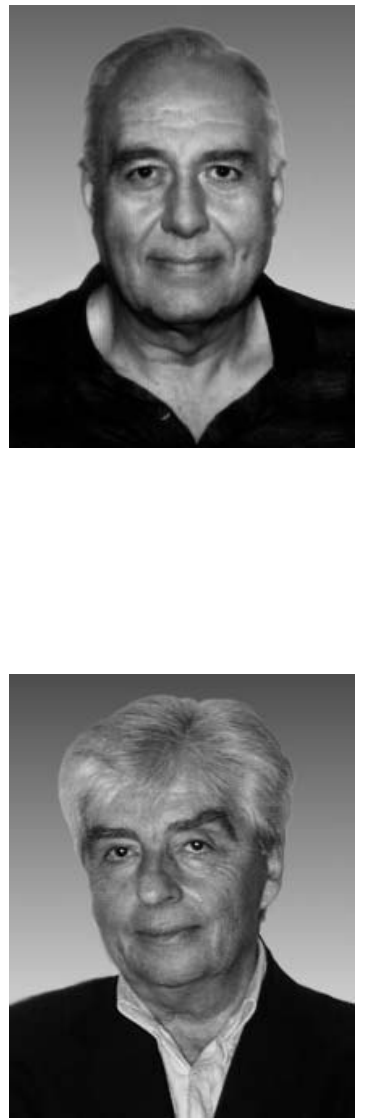